INTERNATIONAL CENTER FOR PUBLIC POLICY
International Center for Public Policy

Working Paper 16-10

October 2016

\section{A Superior Instrument for the Role of Institutional Quality on Economic Development}

\author{
Elizabeth Gooch \\ Jorge Martinez-Vazquez \\ Bauyrzhan Yedgenov
}

GeorgaState University
ANDREWYOUNG SCHOOL

OF POLICY STUDIES 

International Center for Public Policy

Working Paper 16-10

\title{
A Superior Instrument for the Role of Institutional Quality on Economic Development
}

\author{
Elizabeth Gooch \\ Jorge Martinez-Vazquez \\ Bauyrzhan Yedgenov
}

\section{October 2016}

International Center for Public Policy

Andrew Young School of Policy Studies

Georgia State University

Atlanta, Georgia 30303

United States of America

Phone: (404) 413-0235

Fax: (404) 651-4449

Email: paulbenson@gsu.edu

Internet: http://icepp.gsu.edu/

Copyright 2006, the Andrew Young School of Policy Studies, Georgia State University. No part of the material protected by this copyright notice may be reproduced or utilized in any form or by any means without prior written permission from the copyright owner. 


\section{$\underset{\substack{\text { Georgastate } \\ \text { University }}}{\iint_{\text {OF POLICY STUDIES }}} \mid \frac{\text { ANDREW YOUNG SCHOOL }}{\text { OF TOL }}$}

\section{International Center for Public Policy Andrew Young School of Policy Studies}

The Andrew Young School of Policy Studies was established at Georgia State University with the objective of promoting excellence in the design, implementation, and evaluation of public policy. In addition to two academic departments (economics and public administration), the Andrew Young School houses seven leading research centers and policy programs, including the International Center for Public Policy.

The mission of the International Center for Public Policy is to provide academic and professional training, applied research, and technical assistance in support of sound public policy and sustainable economic growth in developing and transitional economies.

The International Center for Public Policy at the Andrew Young School of Policy Studies is recognized worldwide for its efforts in support of economic and public policy reforms through technical assistance and training around the world. This reputation has been built serving a diverse client base, including the World Bank, the U.S. Agency for International Development (USAID), the United Nations Development Programme (UNDP), finance ministries, government organizations, legislative bodies and private sector institutions.

The success of the International Center for Public Policy reflects the breadth and depth of the in-house technical expertise that the International Center for Public Policy can draw upon. The Andrew Young School's faculty are leading experts in economics and public policy and have authored books, published in major academic and technical journals, and have extensive experience in designing and implementing technical assistance and training programs. Andrew Young School faculty have been active in policy reform in over 40 countries around the world. Our technical assistance strategy is not to merely provide technical prescriptions for policy reform, but to engage in a collaborative effort with the host government and donor agency to identify and analyze the issues at hand, arrive at policy solutions and implement reforms.

The International Center for Public Policy specializes in four broad policy areas:

- Fiscal policy, including tax reforms, public expenditure reviews, tax administration reform

- Fiscal decentralization, including fiscal decentralization reforms, design of intergovernmental transfer systems, urban government finance

- Budgeting and fiscal management, including local government budgeting, performancebased budgeting, capital budgeting, multi-year budgeting

- Economic analysis and revenue forecasting, including micro-simulation, time series forecasting,

For more information about our technical assistance activities and training programs, please visit our website at https://icepp.gsu.edu or contact us by email at paulbenson@gsu.edu. 
Development

A Superior Instrument for the Role of Institutional Quality on Economic Development 


\section{By ELIZABETH GOOCH*, JORGE MARTINEZ-VAZQUEZ **, BAUYRZHAN YEDGENOV $^{* * *}$}

October 2016

This paper reexamines the causal link between institutional quality and economic development using "Malaria Endemicity" as an instrument for institutions. This instrument is superior to the previously used instruments in the literature which suffered from measurement error, including "settler mortality." Because the Malaria Endemicity measure captures the malaria environment before the discovery that mosquitoes transmit the disease and before the successful eradication efforts that followed, it is exogenous to both institutional quality and economic development. We find Malaria Endemicity a valid strong instrument which yields larger significant effects of institutions on economic development than those obtained in the previous literature.

JEL Classification: O11; O43; N10; O57. Keywords: Malaria Endemicity, Institutions, Economic Development

\footnotetext{
* Gooch: USDA Economics Research, 1400 Independence Ave., SW, Mailstop 1800, Washington, DC, 20250-0002 (elizabeth.gooch@ers.usda.gov)

** Martinez-Vazquez: International Center for Public Policy (ICePP), Georgia State University, P.O. Box 3992, Atlanta, GA 30302-3992 (jorgemartinez@gsu.edu)

***Yedgenov: International Center for Public Policy (ICePP), Georgia State University, P.O. Box 3992, Atlanta, GA 30302-3992 (baur382@gmail.com)
} 
Development

\section{Introduction}

Ever since the seminal work by Acemoglu Johnson and Robinson (2001) titled "The Colonial Origins of Comparative Development"-- which has been cited almost 9000 times since its publication--, there has been a continuous debate on whether or not institutional quality is the causal key to economic development (henceforth referred to as AJR (2001)). In fact, institutions were hypothesized to be an important factor for economic prosperity decades before AJR's paper was published (Knack and Keefer, 1995; Mauro, 1995; La Porta et al., 1998; Hall and Jones, 1999; Rodrik, 1999 and others). However, prior to AJR (2001) there was no successful attempt to actually identify the causal link between institutional quality and economic development due to severe endogeneity issues such as reverse causality; after all, high quality institutions are perhaps as much a result of economic prosperity as they are their cause. What AJR (2001) offered was a plausible solution to the identification problem. The key was an instrumental variable for institutional quality defined as European colonial settler mortality rates in the countries that were colonized. The idea is that settler mortality rates at the time of colonization identified whether or not European colonizers settled and established "inclusive" institutions or just colonized and established "extractive" institutions. Depending on the type of institutions established, it further conditioned the modern institutional framework, and thus the path to modern economic prosperity. Of course, the sample of countries was limited to countries colonized by Europeans. However, the exercise was not to explain all possible cases, but to use a valid econometric strategy to establish a causal link between institutions and economic development. If the causal link could be established for this sample of countries, then the same causal link should hold for all other countries, other things held constant. 
Being a key to unlock the causal relationship, settler mortality rate was also the weakest link in the chain. Questions about unresolvable measurement error arise from the fact that AJR (2001) Settler Mortality was constructed from a combination of death records ranging from European soldiers to Catholic bishops during times of peace and military campaigns, and that 36 of the 64 country-level observations in their sample were assigned mortality rates from other countries, often based on mistaken or conflicting evidence (Albouy, 2008; Albouy, 2012; Sachs, 2012). The main argument of the doubters was that when these data issues are controlled for, the relationship between mortality and expropriation risk lacks robustness, and the instrumental-variable estimates become unreliable, often with infinite confidence intervals. In other words, the key was imperfect enough to cause doubt that it settles whether or not institutional quality is really behind economic development.

Therefore, our starting point in this paper is that there is still a need for a better key. In this paper we propose such a key, which is a similar instrumental variable that unambiguously defines the settling decision by European colonizers at the time, and consequently the establishment of "good" versus "bad" institutions. What we propose as the instrumental variable is the malaria environment before the 20th century (Malaria Endemicity 1900) while controlling for tropicality and disease stability (Kiszewski, et al., 2004). The disease environment, mainly malaria, was a key factor of settler mortality rates as hypothesized by AJR (2001). In fact, settler mortality rates included death from battles, which is hard to imagine as important in the settling decision for European colonizers who had superior weapons and military tactics. Thus, the malaria environment as a proxy for disease environment at the time of settlement, we argue, is a superior instrument that defines the settlement decisions, and subsequent quality of early and modern institutions. This instrument is more 


\section{Development}

accurate and does not suffer from the type of measurement error present in the proxy used by AJR.

Our key variable describing the malaria risk environment in 1900 at the country level (from here on referred to as Malaria Endemicity 1900) is calculated based on the 1960s World Health Organization publication, "The Geography of Malaria: A Medical-Geographical Study of an Ancient Disease," which mapped the peak distribution of malaria before the medical advances of the 20th century. More specifically, Malaria Endemicity 1900 measures the malaria environment before the discovery that the transmission channel was through mosquitos and therefore before the successful eradication efforts that followed. This measure is exogenous to both institutional quality and economic development. In particular, Malaria Endemicity 1900 reflects the malaria prevalence in earlier centuries because no changes in the disease environment had taken place through those times. For those reasons, Malaria Endemicity 1900 is a good determinant of the disease environment, and the consequent settling decisions of European colonizers to establish "inclusive" versus "extractive" institutions, as proposed by AJR (2001).

In our analysis we find that Malaria Endemicity 1900 performs as a very strong instrument for modern institutions. The instrumented institutional quality variables have significantly larger positive impacts on economic development compared to those from the usual OLS estimation. Moreover, we replicate the results in AJR (2001) and find that Malaria Endemicity 1900 is again a strong instrument. However, we also find that the impact of the average protection from expropriation risk on economic development is lower when instrumented with Malaria Endemicity 1900 — as compared to Settler Mortality. 
The rest of the paper is structured as follows. Section two presents a brief review of the literature. Section three describes the data sources. Section four contains a simplified conceptual framework and section five presents the identification strategy. Section six discusses the empirical results while section seven shows the replication of AJR (2001) findings. Section eight concludes.

\section{Literature Review}

There has been much debate over the determinants of modern economic development, especially between the competing hypotheses emphasizing the role of institutions versus the role of geography, led respectively by Daron Acemoglu and coauthors and Jeffrey Sachs and coauthors. Even though the debate is currently down, there are still many important questions that remain unanswered, especially concerning the validity of the instruments and, in particular, the role played by disease environments on economic growth.

The central argument within the literature about the relationship between disease environments and economic growth is whether or not the effects are ongoing and direct, or historical and indirect. AJR (2001) have argued for an indirect impact of malaria on current economic growth and claim that the prevalence of malaria is highly endogenous, and that the contemporary persistence of malaria stems from the poor institutions of low income countries that were unable to eradicate malaria. Moreover, AJR (2001) express skepticism over malaria's direct effect on economic performance --as has been described by Gallup, et al. (1999) -- which they expected it to work through poor health and high mortality rates. AJR (2001) note that most people living in high malaria areas have developed some immunity to the disease, and if they survive to the age of five, and afterwards, if they get sick most probably it won't be fatal. Therefore, they argue that the effect of malaria has been mainly an indirect one through its 


\section{Development}

effect on settler mortality and the type of institutions established by the settlers, which in turn defined the long-term economic development of countries, including their current performance. In a later paper, Acemoglu, et al. (2002) (henceforth referred to as AJR (2002)) further develop the indirect channel argument for the effect of malaria on economic growth through the type of institutions that got established. The authors argue that since developed areas before colonization were those that were more urbanized and more densely populated, and malaria was more endemic in such areas due to more frequent contacts, Europeans preferred to settle in less dense areas, and hence less endemic areas where they established inclusive institutions. AJR $(2001,2002)$ found in both papers that the malaria variable used by Gallup, et al. (1999) was mostly statistically insignificant by itself as an additional control variable.

Later, following the criticism of AJR (2001, 2002), Gallup and Sachs (2001) and Sachs and Malaney (2002) have used a malaria risk index, which is based on the 1994 world malaria prevalence map by WHO. Their main finding was that even after controlling for institutions, a higher risk of malaria negatively affects current income per capita, thus supporting the argument of a direct link. Gallup and Sachs (2001) and Sachs and Malaney (2002) also add that the reason why AJR (2001) didn't find a direct effect of malaria is because they restricted their data sample to former colonies, which are mainly in the tropics, therefore leading to low variability of the malaria environments. Similar results to those in Gallup and Sachs (2001) and Sachs and Malaney (2002) were reported by Cartensen and Gundlach (2006). These authors argue that even though population in malaria endemic areas develop immunity through sickle cells, these cells affect the health and human capital of the population through sickle cell anemia, and so they also find an independent effect of malaria on GDP per capita after controlling for institutions. 
But it appears that both sides of the argument have been focusing on the wrong measurement of the incidence of malaria. To break the impasse, one would need to measure the prevalence of malaria at the time of colonization by European settlers. This is what we propose to do in this paper by introducing the first exogenous index of historic mosquito-borne disease prevalence. This allows us to make a novel contribution to the literature on the direct versus indirect impact of disease environment on economic growth.

\section{Data}

We use the mean population-weighted malaria endemicity for the county estimated for 1900 as a proxy measure of historical mosquito-borne disease ferocity. This index more accurately captures variation of malaria risk than measures previously used in the empirical literature and is not subject to the confounding impact of 20th century public health campaigns to fight malaria.

Global historical malaria endemicity was first published by Lysenko and Semashko (1968) as part of a World Health Organization (WHO) report and contemporary malariologists have revived the index to characterize historical malaria geography and prevalence (Hay, et al., 2004). Endemicity is an ordered variable, delineated by differences in the parasite rate $(\mathrm{PR})$ for the 2 to 10 -yearold age cohort and captures distribution of malaria in 1900, just before the onset of vector control. The highest endemicity level is holoendemic with $\mathrm{PR}>0.75$; the remaining regions, from high to low, are classified as: hyperendemic with $P R \in(0.5,0.75]$, mesoendemic $P R \in(0.1,0.5]$, hypoendemic $P R \leq 0.1$, and epidemic regions, which include places where some malaria existed as well as malaria-free areas. The PR was constructed from interpolation of data from records of disease and vector presence (e.g., spleen rates, parasite rates, sickle cell incidence, sporozoite rates, and biting rates) and mapped malaria at the peak of its 


\section{Development}

assumed historical distribution, using a combination of expert opinion and climatic measures such as temperature and rainfall isohyets.

We convert the Lysenko and Semashko (1968) map into a GIS dataset made up of grid cells taking the Harvest Choice Grid Database at the one degree resolution (Guo, et al., 2015; Hay, et al., 2004; Lysenko and Semashko, 1968). Then, we calculate the population-weighted mean endemicity for each country $i$ over $\mathrm{j}$ grid cells using the following equation (1).

(1) Malaria Endemicity $1900_{i}=\sum_{j=0}^{N} \frac{\text { Pop. } 1900_{i j}}{\text { Total Pop. } 1900_{i}} \times$ endemicity $_{i j}$

This new country-level variable, Malaria Endemicity 1900, is continuous and mapped in Figure 1 (Gooch, 2017). The distribution of the global population is a backward projection estimated by the History Database of the Global Environment (HYDE). More specifically, HYDE estimates historic population by aligning the 1994 population distribution map of spatial resolution 0.5 degree latitude by 0.5 degree longitude. The data are provided by the National Center for Geographic Information and Analysis (NCGIA) at 0.5 degree resolution extrapolated back in time accounting for population information taken from historical census and continent population growth trends (Klein Goldewijk, 2005; Klein Goldewijk, Beusen, and Janssen, 2010). 


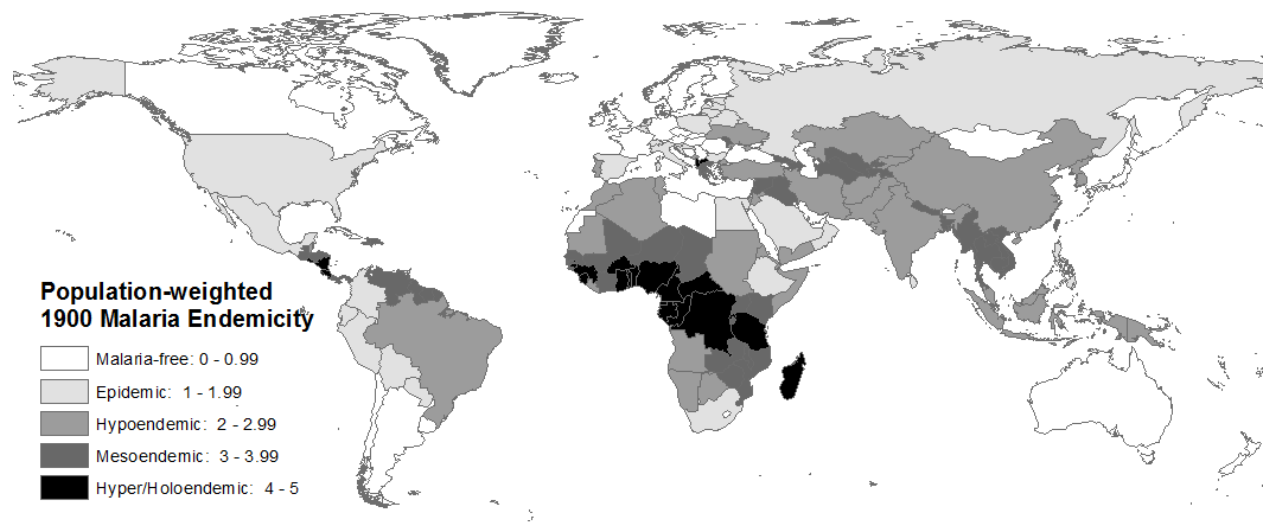

FIGURE 1: MAP OF POPULATION-WEIGHTED MALARIA ENDEMICITY 1900

Notes: Calculated and mapped by authors.

As stated above, a main goal of our research is to extend the literature identifying the direct effects of disease environments and the indirect effects through institutional quality on economic development. Specifically, we use three proxy measures of historic disease environment to complement the currently available proxies for historic disease environment. Empirical research since 1999, has depended on one of the following measures: (1) Settler Mortality (AJR, 2001), (2) measures of Malaria Index during the 20th century (Gallup, et al., 1999; Gallup and Sachs, 2001), and (3) Malaria Ecology (Kiszewski, et al., 2004). Each of these measures has important shortcomings when the objective is to capture actual malaria prevalence in the historical past.

In order to judge the likeness of Settler Mortality in AJR (2001) (of which malaria was one of the main causes) and our own Malaria Endemicity 1900, we conduct a pairwise comparison of proxies and graph the results in Figure 2. Important distinctions between the data sets are: (1) The Settler Mortality dataset is relatively smaller, containing only 64 countries; (2) countries with low Malaria Endemicity 1900 still have relatively high Settler Mortality; and (3) there is a high 


\section{Development}

correlation between Settler Mortality and Malaria Endemicity 1900 for mesoendemic, hyperendemic, and holoendemic countries.

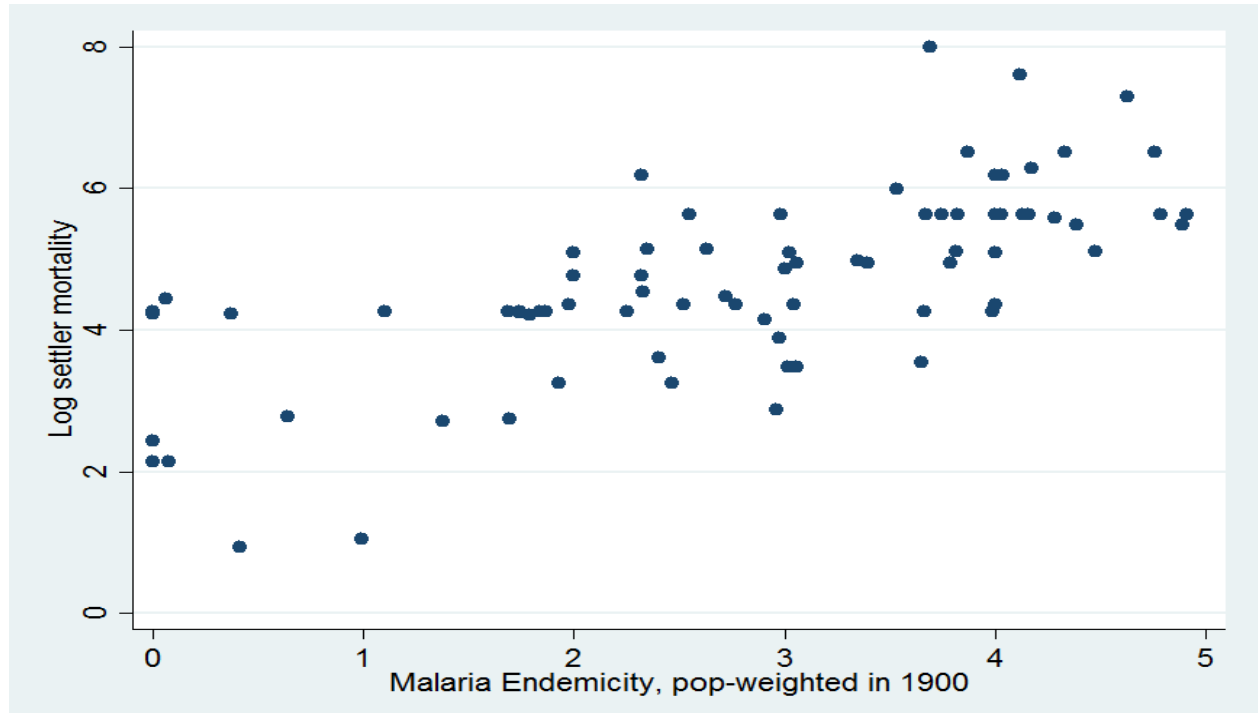

FIGURE 2: PAIRWISE CORRELATION BETWEEN SETTLER MORTALITY AND MALARIA ENDEMICITY 1900 Notes: Settler mortality data comes from AJR (2001)

In their response to AJR (2001), McArthur and Sachs (2001) argued that tropical climates with prevalent infectious disease also have related obstacles to development such as technological innovation. For this purpose, McArthur and Sachs (2001) used the Malaria Index during the 20th century as a time-invariant regional variable. But a post-1900 Malaria Index captures more than just the disease environment as it is influenced by the efficacy of the mosquito control campaigns which in turn were affected by the natural disease stability and quality of the institutions managing the public health campaigns. Therefore, a post-1900 Malaria Index is endogenous. The map in Figure 3 shows the decline of malaria's global distribution between 1900 and 2002 (Hay, et al., 2004). 


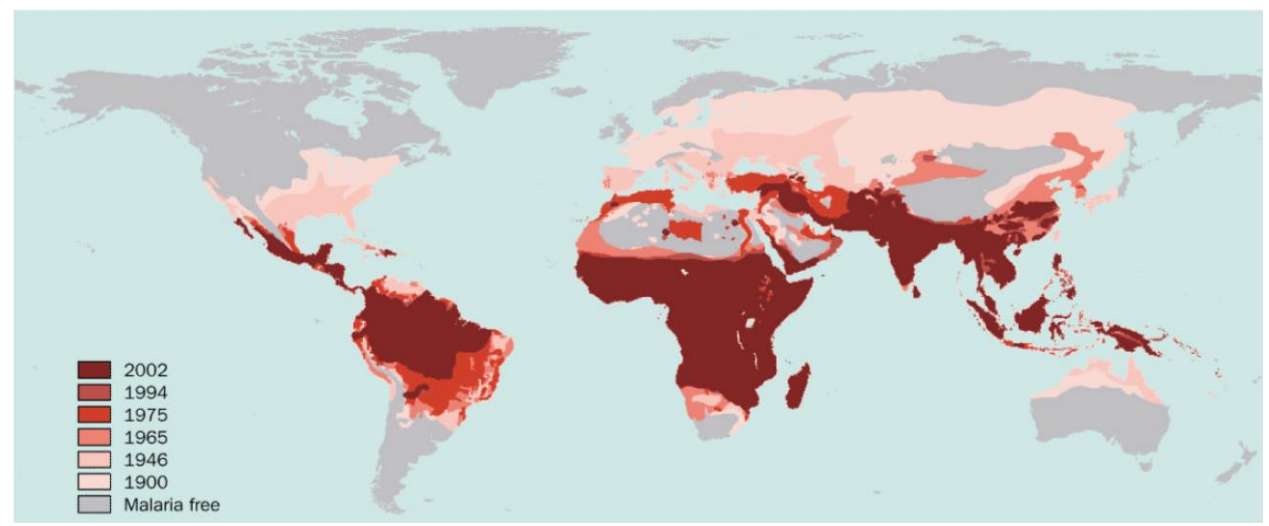

FIGURE 3: THE GLOBAL DISTRIBUTION OF POPULATION AT RISK OF MALARIA: PAST, PRESENT, AND FUTURE

Notes: Hay, et al. (2004)

To illuminate the differences between the Malaria Index in 1994 and our variable, Malaria Endemicity 1900, we have graphed the variables' pairwise correlation in Figure 4. The clusters of countries along the top and bottom edges of the graph suggest that the Malaria Index in 1994 lacks the variation that existed in 1900. The somewhat binary nature of the Malaria Index in 1994 reflects the theory of disease stability, such that 20th century sanitation campaigns in regions with unstable malaria were able to eradicate the disease, while regions with stable malaria continued to have cases (MacDonald, 1952). 


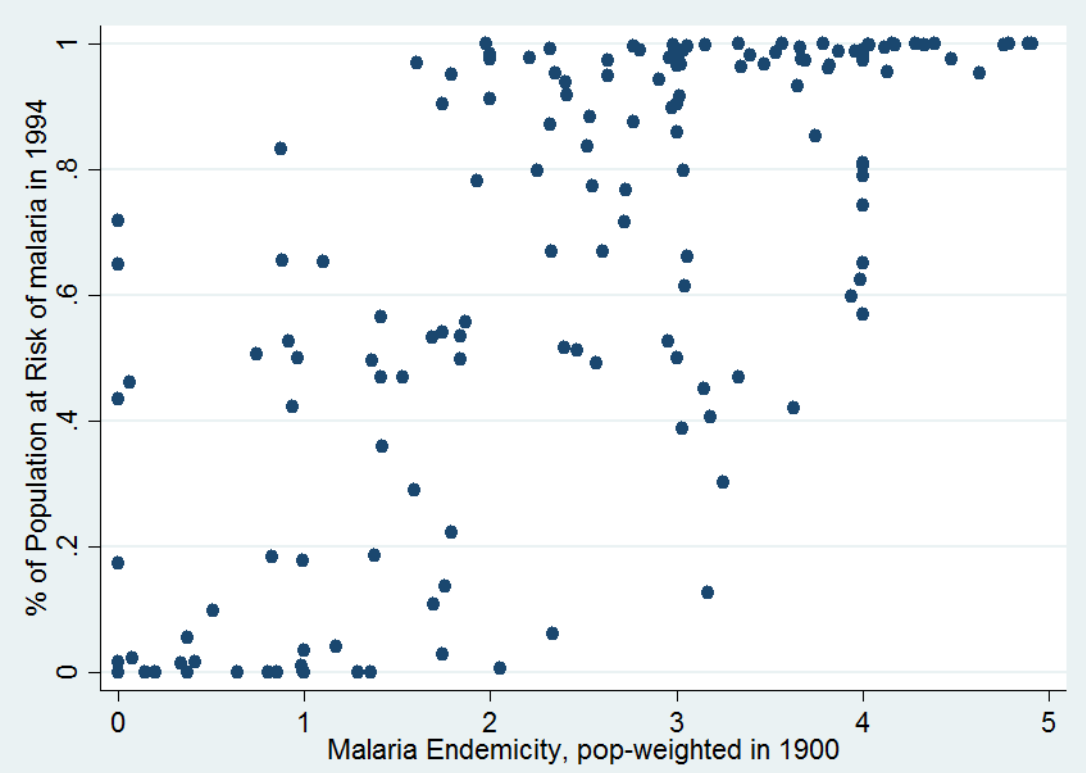

FIGURE 4: PAIRWISE CORRELATION BETWEEN MALARIA RISK IN 1994 AND POPULATION-WEIGTHED MALARIA ENDEMICITY IN 1900

Notes: Malaria risk in 1994 data comes from Gallup and Sachs (2001).

The third measure of malaria disease environment used in the economic development literature has also been taken directly from tropical epidemiological research. Known as Malaria Ecology, this index is based on a formula accounting for temperature, mosquito abundance, and vector specificity, among other climatological and mosquito conditions. Malaria Ecology was created as a spatially disaggregated dataset (Kiszewski, et al., 2004) and it is considered an instrument of malaria risk because its construction relies on regional attributes unaffected by public health interventions and economic conditions. Malaria Ecology has been used widely in empirical analysis of causes of development disparities (Besley and Kudamatsu, 2006; Glaeser, et al., 2004; Henderson, Storeygard, and Weil, 2012; Lorentzen, McMillan, and Wacziarg, 2008; Michalopoulos and Papaioannou, 2013; Nordhaus, 2005; Nunn and Wantechekon, 2011; Nunn and Puga, 2012; Rodrik, Subramanian, and Trebbi, 2004). Recently, 
McCord and Sachs (2013) also used the Malaria Ecology index, which they argue is exogenous to development because it consists of ecological factors and excludes mosquito abundance and human population. They find a highly significant negative effect of the Malaria Ecology index variable on GDP per capita in 2010. They also find a significant (at 5\% confidence level) negative impact of the Malaria Ecology on GDP growth using 1960-2010 data.

Figure 5 illustrates the pairwise comparison of country-level endemicity and ecology indices, which have a correlation of 0.58 . At the country level, we calculate the mean endemicity and ecology index weighted by the population in 1900. As the endemicity index increases along the $\mathrm{x}$-axis, the ecology index does not increase at the same rate. Instead of a proportional increase, values of the ecology index are high for a subsample of countries with high endemicity and which are disproportionately located in Sub-Saharan Africa.

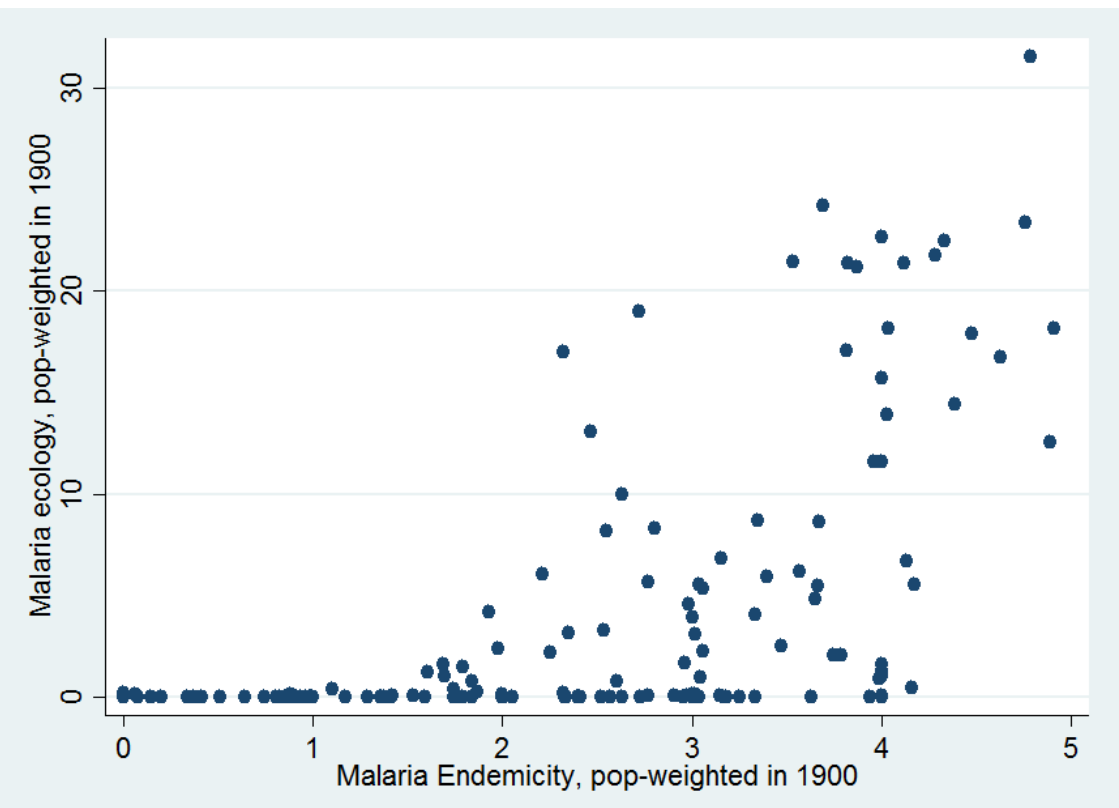

FIGURE 5: PAIRWISE CORRELATION BETWEEN MALARIA ECOLOGY AND MALARIA ENDEMICITY 1900 Notes: Malaria ecology data comes from Kiszewski, et al. (2004). 


\section{Development}

To exemplify this difference, we compare eight malaria-prone countries from five continents: Bangladesh, Myanmar, Honduras, Mali, Chad, Senegal, Ivory Coast, and Costa Rica. All have a population-weighted endemicity index of 3.6 to 3.9 , which characterizes them as mesoendemic countries and just below the hyperendemic category. Their population-weighted ecology indices, however, are very different. African countries have population-weighted ecology indices of 17 to 24 , while non-African countries have indices less than 2 . The ecology index heavily weights the prevalence of malaria in Sub-Saharan Africa, even though nearly 50 percent of each of these countries' 2-10-year-old cohort had malaria symptoms in 1900.

The ecology index provides an accurate account of the success of vector control in terms of eradication or intense suppression but does not capture the prevalence of malaria that historical communities encountered. As described in (Kiszewski et al. 2004) and depicted in figure 5, the ecology index displays a sharp transition from unsuitable ecology to suitable ecology. This abrupt change resembles the transition from the unstable steady-state to the stable steady-state central to malaria transmission models (Hay, Smith, and Snow, 2008; MacDonald, 1952; Ross, 1911). A simple way to understand the difference between these steady states is that stable malaria is difficult to suppress, while the transmission cycle of unstable malaria is easy to interrupt. Thus, regions where MBD was eradicated had naturally unstable malaria, or a low ecology index.

We welcome the differences between Malaria Ecology in 1900 and Malaria Endemicity 1900 because together the two indices capture more information about the conditions prevalent in the past. By controlling for Malaria Ecology in 1900 which captures the resiliency of malaria to shocks, both natural and anthropogenic, Malaria Endemicity 1900 then accurately measures suffering due to malaria during the time of colonization, and not later. 


\section{Conceptual Framework}

Malaria Endemicity captures the geographic distribution and intensity of mosquito-borne disease, and was a time invariant characteristic of a region prior to 1900. After the discovery of the malaria amoeba, Plasmodium, in the mosquito saliva in 1898, widespread interruption of malaria and yellow fever transmission began, and in turn disease incidence decreased in many areas.

The historic and exogenous nature of our variable, Malaria Endemicity 1900, allows us to employ the conceptual framework introduced by AJR (2001) and substitute Malaria Endemicity 1900 for their Settler Mortality variable. Intuitively, AJR (2001) use Settler Mortality as a snapshot of the disease environment during the time of colonization and we propose that Malaria Endemicity 1900 offers a superior snapshot of the morbidity and mortality consequences of malaria. Unlike the narrow connection between observations on Settler Mortality rate in a colony and the quality of the colonial institutions, Malaria Endemicity 1900 likely has a broader influence on historic developments such as indigenous advancement. For that reason we include additional covariates in our analysis to capture potential variation in the early progress of those countries. Additionally, Malaria Endemicity 1900 is related to the efficacy of suppression campaigns through its high correlation with disease stability (MacDonald 1952). We eliminate this confounding influence on 20th century economic growth by controlling for disease stability using the covariate Malaria Ecology.

The indirect effect of Malaria Endemicity 1900 on current economic growth is based on its determining effect on the settling of European colonists and the different institutional frameworks that developed depending on the extent and presence of the disease, as hypothesized by AJR (2001). Recall that the main 


\section{Development}

argument is that malaria and the overall disease environment affected settler mortality, which in turn defined the type of institutions established (extractive versus inclusive), which finally affected the long-term development of the country, including its current economic state. The line of causation is illustrated in Figure 6.

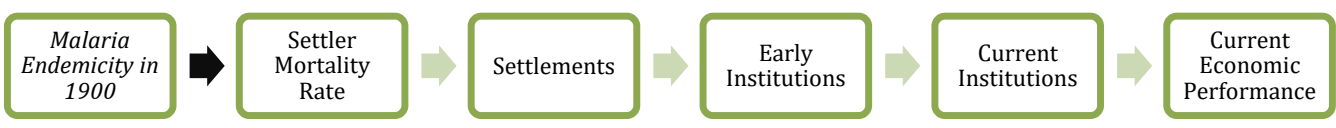

FIGURE 6: REVISION OF SCHEMATIC SUMMARY OF MECHANISMS LINKING MALARIA ENDEMICITY IN 1900 TO CURRENT ECONOMIC PREFORMANCE (ACEMOGLU, ET AL., 2001)

Contrarily, Malaria Ecology 1900 is time invariant and, therefore, the variation in the disease environment captured by Malaria Ecology persists through each stage of the progression, from affecting the settlers' mortality rate to current institutional quality and economic performance. The time invariance nature of Malaria Ecology does not meet the necessary requirements of an instrumental variable for this research question. However, the time invariant nature of Malaria Ecology 1900 provides us with an opportunity to control for the likelihood of successful eradiation and suppression efforts during the 20th century, thereby keeping Malaria Endemicity 1900 as a snapshot of only historic malaria. Proponents of the direct effects of malaria led by Sachs and others argue that the consequences of this deadly disease affected the level of development before the 20th century and that it continues to directly affect the current economic development of countries affected by malaria, most of which are in Africa. 


\section{Identification Strategy}

The main contribution of this paper is the use of exogenous Malaria Endemicity 1900 as an instrument variable, capturing an exogenous source of variation in historic institutional quality, which allows us to properly identify and measure the causal impact of institutional quality on economic growth.

To begin with, we conduct a reduced form analysis of the relationship between pre-anthropogenic malaria prevalence, Malaria Endemicity 1900, and current measures of development using the following specification:

$$
y_{i}=\beta_{0}+\beta_{1} \text { Malaria Risk } 1900+\boldsymbol{C}_{i}^{\prime} \delta+\boldsymbol{X}_{i}^{\prime} \gamma+\varepsilon_{i}
$$

The dependent variable, $y_{i}$, captures the variation in development for modern-day country, i. The variable of interest, Malaria Endemicity 1900, is indexed by the average malaria prevalence for country i. The vector, $C_{i}^{\prime}$, contains time invariant characteristics of the country which includes Malaria Ecology 1900 (Kiszewski, et al., 2004). Continent and colonizer indicator variables are contained in the vector, $X_{i}^{\prime}$. The summary statistics for the variable of interest, outcomes, and relevant covariates are presented in table 1. 


\section{Development}

TABLE 1: SUMMARY STATISTICS

\begin{tabular}{|c|c|c|c|c|c|}
\hline & Number & & Std. & & \\
\hline VARIABLES & of obs. & Mean & Dev. & Minimum & Maximum \\
\hline Malaria Ecology (1900 Population-weighted) & 161 & 3.827 & 6.826 & 0.000 & 31.556 \\
\hline Rule of Law 1996 & 157 & -0.174 & 0.984 & -2.203 & 2.023 \\
\hline Log [population density in $1500 \mathrm{CE}$ ] & 155 & 0.862 & 1.471 & -3.817 & 3.842 \\
\hline Log [Neolithic transition timing (1500 CE baseline)] & 149 & 8.196 & 0.692 & 5.704 & 9.210 \\
\hline Log [absolute latitude] & 159 & 2.967 & 0.957 & 0.000 & 4.277 \\
\hline Log [land suitability for agriculture] & 153 & -1.482 & 1.364 & -5.857 & -0.041 \\
\hline Log [temperature] & 158 & 3.602 & 0.384 & -0.000 & 3.894 \\
\hline Log [precipitation] & 158 & 4.188 & 0.906 & 1.068 & 5.560 \\
\hline WGI 1996 & 156 & -0.171 & 0.938 & -2.235 & 1.836 \\
\hline GDP 1950 & 124 & 7.283 & 0.969 & 5.667 & 10.322 \\
\hline GDP 1975 & 124 & 7.897 & 1.077 & 6.239 & 10.469 \\
\hline GDP 2000 & 145 & 8.123 & 1.159 & 5.380 & 10.256 \\
\hline $\log [\%$ Within $100 \mathrm{~km}$. of Ice-free Coast] & 159 & 2.797 & 1.652 & 0.000 & 4.615 \\
\hline $\log [$ Percent Tropical +1$]$ & 159 & 1.942 & 2.152 & 0.000 & 4.615 \\
\hline Log[Avg. Terrain Ruggedness] & 159 & -0.159 & 0.993 & -3.310 & 1.908 \\
\hline
\end{tabular}

By using a reduced form specification, the mechanism through which Malaria Endemicity 1900 affects contemporary economic performance is uncertain. Therefore, in order to confine the impact of Malaria Endemicity 1900 on current-day outcomes exclusively through early institutional quality, we employ a 2SLS estimation strategy:

$$
\begin{aligned}
& y_{i}=\pi_{0}+\square_{1} \text { Early Institutional Quality }(I V: \text { Malaria Risk 1900) }+ \\
& \boldsymbol{C}_{i}^{\prime} \rho+\boldsymbol{X}_{i}^{\prime} \mu+\varphi_{i}
\end{aligned}
$$

Almost all variables are the same in equation (2) and (3), except that in the 2SLS specification the coefficient of interest, $\pi_{1}$, captures the impact of early institutional quality on current economic performance by only exploiting variation 
in Malaria Endemicity 1900, while in the OLS reduced form equation, the coefficient of interest, $\beta_{1}$, measures the general impact of Malaria Endemicity 1900 on current-day economic performance.

We assert that Malaria Endemicity 1900 satisfies the three criteria for a valid instrumental variable when Malaria Ecology 1900 is included as a covariate. Specifically, Malaria Endemicity 1900: (1) is unrelated to an area's potential for both economic growth and institutional quality, (2) has a non-weak relationship with institutional quality during colonial times and current-day, and (3) the nonweak relationship is a monotonic relationship, all of which prevail when disease stability, Malaria Ecology 1900, is taken into account.

The first criterion is analogous to the assumption $\operatorname{Cov}(Z, \xi)$ which is untestable, and particularly difficult to support using an exactly identified IV model. In our model, we control for the confounding influence of tropicality and malaria stability that is commonly correlated with both malaria prevalence and economic growth. By taking into account tropicality, which has been cited to inhibit capital accumulation, and malaria stability, which is inversely related to the success of malaria suppression campaigns, we propose that the level of Malaria Endemicity in 1900 is otherwise exogenous.

The other two criteria, taken together, require that the IV have a non-weak monotonic relationship with institutional quality. Evidence of a non-weak relationship between Malaria Endemicity 1900 and institutional quality is provided by the Cragg-Donald statistic in Table 3, which tests the null hypothesis that the first-stage relationship is weak. In our analysis, the null hypothesis is rejected. Finally, the relationship between Malaria Endemicity 1900 and institutional quality needs to be monotonic. Following our modified line of causation depicted in figure 6, greater Malaria Endemicity 1900 led to greater 
Settler Mortality which, in turn, led to poorer institutional quality, never the reverse. Malaria Endemicity 1900, therefore, meets the necessary conditions to be a valid IV.

\section{Empirical Results}

We hypothesize that Malaria Endemicity 1900 only has an indirect effect on contemporary economic growth through the development of institutional quality during the 20th century because it was time invariant only until 1900, thus only affecting historic institutional quality.

In Table 2, we present the reduced form relationship between Malaria Endemicity 1900 and five measures of modern development: the log of real per capita GDP in 1950, 1975, and 2000, as well as the average World Governance Indicator in 1996 and Rule of Law in 1996 (Kaufmann, Kraay, and Mastruzzi 2010; Maddison-Project (2013). 
TABLE 2: REDUCED-FORM RELATIONSHIP BETWEEN MALARIA ENDEMICITY 1900 AND DEVELOPMENT INDICATORS

\begin{tabular}{|c|c|c|c|c|c|}
\hline & (1) & (2) & (3) & (4) & (5) \\
\hline VARIABLES & GDP 1950 & GDP 1975 & GDP 2000 & WGI 1996 & Rule of Law 1996 \\
\hline Malaria Endemicity (1900 Population- & -0.142 & -0.113 & -0.278 & -0.272 & -0.287 \\
\hline weighted) & -0.098 & -0.093 & -0.072 & -0.066 & -0.07 \\
\hline Malaria Ecology (1900 Population- & -0.008 & -0.012 & -0.021 & -0.001 & 0.001 \\
\hline weighted) & -0.014 & -0.014 & -0.016 & -0.014 & -0.016 \\
\hline \multirow[t]{2}{*}{ Log [temperature] } & -0.494 & -0.285 & -0.098 & -0.291 & -0.257 \\
\hline & -0.483 & -0.521 & -0.482 & -0.514 & -0.544 \\
\hline \multirow[t]{2}{*}{ Log [precipitation] } & 0.092 & 0.005 & 0.261 & 0.37 & 0.359 \\
\hline & -0.193 & -0.204 & -0.212 & -0.196 & -0.215 \\
\hline \multirow[t]{2}{*}{ Log [absolute latitude] } & -0.173 & -0.263 & -0.153 & 0.04 & 0.068 \\
\hline & -0.109 & -0.148 & -0.12 & -0.092 & -0.103 \\
\hline \multirow[t]{2}{*}{ Log[Percent Tropical +1] } & -0.103 & -0.165 & -0.195 & -0.125 & -0.14 \\
\hline & -0.078 & -0.092 & -0.09 & -0.08 & -0.087 \\
\hline \multirow[t]{2}{*}{ Log[Avg. Terrain Ruggedness] } & -0.176 & -0.14 & -0.129 & -0.076 & -0.051 \\
\hline & -0.104 & -0.097 & -0.081 & -0.076 & -0.085 \\
\hline \multirow[t]{2}{*}{$\log [\%$ Within $100 \mathrm{~km}$. of Ice-free Coast $]$} & 0.16 & 0.201 & 0.158 & 0.07 & 0.086 \\
\hline & -0.053 & -0.055 & -0.048 & -0.045 & -0.048 \\
\hline \multirow[t]{2}{*}{ Log [land suitability for agriculture] } & -0.141 & -0.079 & -0.093 & -0.128 & -0.163 \\
\hline & -0.098 & -0.103 & -0.093 & -0.081 & -0.093 \\
\hline Log [Neolithic transition timing (1500 CE & 0.194 & 0.228 & 0.21 & -0.104 & -0.059 \\
\hline baseline)] & -0.174 & -0.142 & -0.218 & -0.2 & -0.214 \\
\hline \multirow[t]{2}{*}{ Log [population density in $1500 \mathrm{CE}$ ] } & -0.03 & -0.1 & 0.003 & 0.063 & 0.104 \\
\hline & -0.072 & -0.085 & -0.078 & -0.064 & -0.071 \\
\hline Observations & 120 & 120 & 141 & 146 & 146 \\
\hline R-squared & 0.65 & 0.719 & 0.74 & 0.627 & 0.608 \\
\hline Continent FE & YES & YES & YES & YES & YES \\
\hline Colonizer FE & YES & YES & YES & YES & YES \\
\hline
\end{tabular}

In Table 3, we present our empirical estimation of the impact of institutional quality on economic growth using Malaria Endemicity 1900 as the instrumental variable and also including a large number of covariates, in particular, Malaria Ecology 1900. We report the OLS relationship between institutional quality and economic development for comparison purposes. The estimates presented in columns (4) and (5) of Table 1 can be used to check the 


\section{Development}

first-stage relationship between Malaria Endemicity 1900 and institutional quality. The Cragg-Donald statistic at the bottom of table 3 provides evidence that Malaria Endemicity 1900 is a non-weak instrument (Bound, Jaeger, and Baker, 1995; Cragg and Donald, 1993; Stock and Yogo, 2005).

The estimates of institutional quality show that when instrumented with Malaria Endemicity 1900, the impact of institutional quality on economic development is considerably larger. The magnitude of the positive impact increases from 0.834 to 1.175 , or approximately a $42 \%$ increase in the case of the WGI indicator; and from 0.695 to 0.945 , or approximately a $51 \%$ increase in the case of the Rule of Law indicator. In other words, the impact of institutional quality appears to be largely underestimated when using OLS estimation, which doesn't account for the endogeneity issue. 
TABLE 3: OLS AND IV ESTIMATES FOR THE RELATIONSHIP BETWEEN MALARIA ENDEMICITY 1900 AND PER CAPITA INCOME IN 2000

\begin{tabular}{|c|c|c|c|c|}
\hline & (1) & (2) & (3) & (4) \\
\hline & \multicolumn{4}{|c|}{ Dependent variable: $\ln ($ Real GDP per capita 2000) } \\
\hline & OLS & IV & OLS & IV \\
\hline \multirow[t]{2}{*}{ WGI 1996} & 0.834 & 1.175 & & \\
\hline & -0.058 & -0.155 & & \\
\hline \multirow[t]{2}{*}{ Rule of Law 1996} & & & 0.695 & 0.945 \\
\hline & & & -0.059 & -0.172 \\
\hline \multirow[t]{2}{*}{ Malaria Ecology (1900 Population-weighted) } & & & -0.023 & -0.020 \\
\hline & & & -0.013 & -0.012 \\
\hline \multirow[t]{2}{*}{ Log [temperature] } & & & 0.007 & 0.161 \\
\hline & & & -0.379 & -0.321 \\
\hline \multirow[t]{2}{*}{ Log [precipitation] } & & & 0.001 & -0.096 \\
\hline & & & -0.155 & -0.142 \\
\hline \multirow[t]{2}{*}{ Log [absolute latitude] } & & & -0.189 & -0.219 \\
\hline & & & -0.099 & -0.091 \\
\hline \multirow[t]{2}{*}{ Log[Percent Tropical +1] } & & & -0.117 & -0.071 \\
\hline & & & -0.069 & -0.062 \\
\hline \multirow[t]{2}{*}{ Log[Avg. Terrain Ruggedness] } & & & -0.102 & -0.077 \\
\hline & & & -0.053 & -0.055 \\
\hline \multirow[t]{2}{*}{$\log [\%$ Within $100 \mathrm{~km}$. of Ice-free Coast] } & & & 0.105 & 0.082 \\
\hline & & & -0.035 & -0.034 \\
\hline \multirow[t]{2}{*}{ Log [land suitability for agriculture] } & & & 0.004 & 0.066 \\
\hline & & & -0.067 & -0.073 \\
\hline \multirow[t]{2}{*}{ Log [Neolithic transition timing (1500 CE baseline)] } & & & 0.145 & 0.185 \\
\hline & & & -0.108 & -0.122 \\
\hline \multirow[t]{2}{*}{ Log [population density in $1500 \mathrm{CE}$ ] } & & & -0.054 & -0.094 \\
\hline & & & -0.047 & -0.055 \\
\hline Observations & 145 & 145 & 141 & 141 \\
\hline R-squared & 0.785 & 0.745 & 0.865 & 0.844 \\
\hline Continent FE & YES & YES & YES & YES \\
\hline Colonizer FE & YES & YES & YES & YES \\
\hline Cragg-Donald Stat. & & 35.8 & & 15.31 \\
\hline
\end{tabular}

Notes: Robust standard errors are reported below coefficients. 
Development

\section{Malaria Endemicity 1900 as a Substitute for Settler Mortality Data: A Replication of AJR (2001)}

In this section we replicate the results in AJR (2001) using Malaria Endemicity 1900 as a substitute for Settler Mortality because of its superiority, we argue, as an instrumental variable in the settling decisions made by Europeans. As in AJR (2001), the modern institution is measured as the Average protection against expropriation risk. The summary statistics for the variable of interest, outcomes, and covariates from AJR (2001) are presented in table 4.

TABLE 4: SUMMARY STATISTICS OF MALARIA ENDEMICITY 1900 AND MALARIA ECOLOGY FOR REPLICATION OF AJR'S (2001) TABLES

\begin{tabular}{lccccc}
\hline & $\begin{array}{c}\text { Number } \\
\text { of obs. }\end{array}$ & Mean & $\begin{array}{c}\text { Std. } \\
\text { Dev. }\end{array}$ & Minimum & Maximum \\
Malaria Ecology (1900 Population-weighted) & 80 & 6.708 & 8.447 & 0.000 & 31.556 \\
Malaria Endemicity (1900 Population-weighted) & 80 & 2.825 & 1.342 & 0.000 & 4.912 \\
European settlers 1900, AJR & 79 & 15.449 & 27.345 & 0.000 & 100.000 \\
average protection against expropriation risk & 69 & 6.481 & 1.574 & 3.500 & 10.000 \\
log PPP GDP pc in 1995, World Bank & 74 & 7.948 & 1.012 & 6.109 & 10.216 \\
democracy in 1900 & 70 & 1.414 & 2.810 & 0.000 & 10.000 \\
constraint on executive in 1900 & 73 & 2.068 & 1.981 & 1.000 & 7.000 \\
log Settler Mortality & 80 & 4.679 & 1.303 & 0.936 & 7.986 \\
Absolute latitude & 80 & 16.707 & 12.599 & 1.000 & 60.000
\end{tabular}

Already established by AJR (2001), early institutional quality is a strong predictor of modern institutional quality; the constraint on executive in 1900 and democracy in 1900 are positive and significant determinants of modern institutions even after controlling for absolute latitude. The results in table 5 correspond to table $3 \mathrm{~b}$ from AJR (2001), and we examine the relationship between the indices of historical mosquito-borne disease environment (Settler 
Mortality and Malaria Endemicity 1900) and the institutional quality variables of interest. $^{2}$

Like Settler Mortality, Malaria Endemicity 1900 is a strong predictor of early institutions. When comparing the coefficients in columns 1 and 2 for which the dependent variable is constraint on the executive in 1900, the coefficient for settler mortality is larger than the coefficient for Malaria Endemicity 1900 (The difference is statistically significant at $10 \%$, p-value $=0.08)$. Since the Settler Mortality variable has been cited for measurement error and has a stronger relationship with institutional quality, it may be the case that Settler Mortality overestimates the impact on early institutions (Albouy, 2008). When comparing columns 3 and 4 for which the dependent variable is democracy in 1900, the consistently negative relationship and difference between two coefficients is repeated.

In columns 5 and 6 of table 5, Settler Mortality and Malaria Endemicity 1900 are both positive predictors of the percent of European settlers in a colony and the two coefficients are not statistically different from one another. In fact, as shown in column 7, Malaria Endemicity 1900 is a significant positive determinants of overall Settler Mortality, and explains almost half of the variation in overall Settler Mortality. ${ }^{3}$

\footnotetext{
2 The results are not an exact replication because, AJR (2001) replication data does not list an identifier for the country to be able to merge with the malaria data.

${ }^{3}$ Overall Settler Mortality also suffers from measurement errors and that it may not reflect accurately the actual overall mortality rate.
} 


\section{Development}

TABLE 5: REPLICATION OF TABLE 3, PANEL B OF AJR (2001): USING MALARIA ENDEMICITY 1900 AS A SUBSTITUTE FOR SETTLER MORTALITY

\begin{tabular}{|c|c|c|c|c|c|c|c|}
\hline & (1) & (2) & (3) & (4) & (5) & (6) & (7) \\
\hline & \multicolumn{2}{|c|}{ Constraint on Executive } & \multicolumn{2}{|c|}{ Democracy } & \multicolumn{2}{|c|}{ European settlers } & $\begin{array}{l}\text { Log Settler } \\
\text { Mortality }\end{array}$ \\
\hline \multirow{2}{*}{$\begin{array}{l}\text { Log Settler } \\
\text { Mortality }\end{array}$} & -0.744 & & -0.984 & & -8.588 & & \\
\hline & -0.191 & & -0.266 & & -2.105 & & \\
\hline \multirow[t]{2}{*}{ Absolute latitude } & 0.034 & 0.034 & 0.078 & 0.084 & 0.938 & 0.666 & -0.013 \\
\hline & -0.02 & -0.021 & -0.028 & -0.031 & -0.217 & -0.21 & -0.011 \\
\hline \multirow[t]{2}{*}{$\begin{array}{l}\text { Malaria } \\
\text { Endemicity }\end{array}$} & & -0.578 & & -0.650 & & -10.482 & 0.558 \\
\hline & & -0.18 & & -0.261 & & -1.796 & -0.093 \\
\hline Observations & 71 & 71 & 65 & 65 & 67 & 67 & 68 \\
\hline R-squared & 0.318 & 0.276 & 0.395 & 0.328 & 0.518 & 0.604 & 0.506 \\
\hline
\end{tabular}

Continuing with the replication, in column 1 of Table 6 , we re-estimate the specification from AJR's (2001) Table 4, column 8 which measures the impact of average protection against expropriation risk on per capita income in 1995. We chose to re-estimate the specification because it comes from the most conservative specification. Even though our estimates do not match AJR (2001) exactly, they are similar. The small Cragg-Donald statistic at the bottom of panel A and the statistically insignificant coefficient in panel B provides evidence that Settler Mortality may be a weak instrument. In column 2, we re-estimate the impact of average protection against expropriation risk on per capita income in 1995 using Settler Mortality as an instrument again but including the covariates from our specifications in columns 3 and 4, when we use Malaria Endemicity 1900 as an instrument, which are Malaria Ecology and tropicality. The first-stage relationship in column 2 is not different than that in column 1, the Cragg-Donald statistics remain small, and the second-stage estimates are significantly smaller. 
TABLE 6: REPLICATION OF TABLE 4 FROM AJR (2001): IMPACT OF INSTITUTIONAL QUALITY ON MODERN PER CAPITA INCOME USING MALARIA ENDEMICITY 1900 AS IV

\begin{tabular}{|c|c|c|c|c|}
\hline & (1) & $(2)$ & (3) & (4) \\
\hline Panel A: Second-stage Estimates & \multicolumn{4}{|c|}{ Dep. variable: log PPP GDP pc in 1995} \\
\hline \multirow[t]{2}{*}{ Average protection against expropriation risk } & 0.836 & 0.585 & 0.679 & 0.481 \\
\hline & -0.401 & -0.256 & -0.234 & -0.14 \\
\hline \multirow[t]{2}{*}{$\%$ Tropical climate } & & -0.004 & -0.006 & -0.003 \\
\hline & & -0.004 & -0.003 & -0.003 \\
\hline \multirow[t]{2}{*}{ Malaria Ecology (1900 Population-weighted) } & & -0.015 & -0.01 & -0.017 \\
\hline & & -0.013 & -0.015 & -0.012 \\
\hline \multirow[t]{2}{*}{ Absolute latitude } & -0.014 & -0.013 & -0.028 & -0.006 \\
\hline & -0.022 & -0.02 & -0.018 & -0.013 \\
\hline \multirow[t]{2}{*}{ Africa dummy } & -0.658 & -0.718 & -0.789 & -0.740 \\
\hline & -0.307 & -0.241 & -0.282 & -0.215 \\
\hline \multirow[t]{2}{*}{ Asia dummy } & -1.017 & -0.926 & -0.367 & -0.876 \\
\hline & -0.326 & -0.24 & -0.197 & -0.2 \\
\hline \multirow[t]{2}{*}{ Continent dummy } & -0.93 & -0.478 & -0.505 & -0.255 \\
\hline & -0.984 & -0.687 & -0.639 & -0.482 \\
\hline Cragg-Donald Stat. & 2.372 & 3.029 & 6.695 & 9.19 \\
\hline Panel B: First-stage Estimates & \multicolumn{4}{|c|}{ Dep. variable: average protection against expropriation risk } \\
\hline \multirow[t]{2}{*}{ Log Settler Mortality } & -0.222 & -0.258 & & \\
\hline & -0.166 & -0.19 & & \\
\hline \multirow[t]{2}{*}{ Malaria Endemicity (1900 Population-weighted) } & & & -0.360 & -0.464 \\
\hline & & & -0.147 & -0.194 \\
\hline \multirow[t]{2}{*}{$\%$ Tropical climate } & & 0.005 & 0.008 & 0.012 \\
\hline & & -0.007 & -0.005 & -0.007 \\
\hline \multirow[t]{2}{*}{ Malaria Ecology (1900 Population-weighted) } & & 0.003 & 0.008 & 0.002 \\
\hline & & -0.031 & -0.028 & -0.028 \\
\hline \multirow[t]{2}{*}{ Absolute latitude } & 0.042 & 0.055 & 0.064 & 0.063 \\
\hline & -0.014 & -0.022 & -0.014 & -0.021 \\
\hline \multirow[t]{2}{*}{ Africa dummy } & -0.426 & -0.307 & -0.41 & 0.075 \\
\hline & -0.403 & -0.531 & -0.487 & -0.551 \\
\hline \multirow[t]{2}{*}{ Asia dummy } & 0.279 & 0.323 & -0.236 & 0.612 \\
\hline & -0.449 & -0.459 & -0.361 & -0.466 \\
\hline \multirow[t]{2}{*}{ Continent dummy } & 1.688 & 1.726 & 1.245 & 1.506 \\
\hline & -0.957 & -0.983 & -0.963 & -0.952 \\
\hline Observations & 69 & 69 & 110 & 69 \\
\hline R-squared & 0.415 & 0.421 & 0.535 & 0.455 \\
\hline Dataset & AJR (2001) & AJR (2001) & ALL & AJR (2001) \\
\hline
\end{tabular}


In columns 3 and 4 of Table 6, we estimate impact of average protection against expropriation risk on per capita income in 1995 using Malaria Endemicity 1900 as the instrument. The Cragg-Donald statistics are larger than when Settler Mortality is used as an instrument but still too small to ensure a non-weak instrument; but the first-stage coefficients in panel B are highly significant. The difference between column 3 and 4 is related to the size of the data sample used. In column 3 we include all countries for which data are available, while in column 4, we include only those countries which were used in AJR (2001). The coefficient in column 3 is significantly larger than the coefficient in column 4 and not significantly different from the estimate in column 2, which used Settler Mortality as an instrument. However, since neither of these instruments is nonweak, then all of the second-stage estimates may not be consistent (Chao and Swanson, 2005; Bound, Jaeger, and Baker, 1995).

\section{Conclusion}

In this paper we contribute to debate on whether institutional quality is the causal key to economic development. As we have seen, prior to AJR (2001) the causal link between institutional quality and economic development was put into question because of the severe endogeneity involved due to the fact that high quality institutions can be as much the result of economic prosperity as they are their cause. What AJR (2001) offered was a plausible solution to the identification problem by using European colonial settler mortality rates as an instrumental variable for institutional quality. However, that instrumental variable has been questioned on the basis of unresolvable measurement errors including that more than half of the sample countries were assigned mortality rates from other countries, often based on mistaken or conflicting evidence. The result has been that the relationship between mortality and expropriation risk - the main 
institutional quality indicator used in AJR (2001)-- appears to lack robustness, with the mortality rates instrumental-variable estimates becoming unreliable.

In this paper we propose a substitute instrumental variable-- Malaria Endemicity 1900 - that is superior to AJR's mortality rate in defining settlement decisions and subsequent quality of early and modern institutions, when malaria stability is accounted for (Kiszewski, et al., 2004; MacDonald, 1952). Malaria Endemicity 1900 measures the malaria environment before the discovery that the transmission channel was through mosquitos and the successful malaria eradication efforts that followed (Hay, et al., 2004; Lysenko and Semashko, 1968). Therefore, this measure is exogenous to both institutional quality and economic development. In this paper we have argued that that Malaria Endemicity 1900 is a superior measure of disease and mortality environment that affected the settling decisions of European colonizers in establishing "inclusive" versus "extractive" institutions. The main question is would malaria environment have had a significant impact on economic development if proper, high quality institutions were in place? We believe the answer is no, and therefore the impact of malaria is only through institutional quality, which makes it an appropriate instrument. Our estimation results confirm the strength of Malaria Endemicity 1900 as an instrument for the quality of institutions.

In our analysis, we find that Malaria Endemicity 1900 performs as a very strong instrument for modern institutions. In particular, we find that the impact of institutional quality is higher when instrumented by Malaria Endemicity 1900 compared to the estimation results using OLS. In replicating the findings in AJR (2001) using Malaria Endemicity 1900 we find a lower impact of average protection from expropriation risk on economic development compared to the results obtained using Settler Mortality as an instrument. 
Development

The results obtained in this paper may not necessarily provide the definitive answer to the debate on the role of institutional quality in economic development. However, they directly address the criticisms of the instrument used by AJR (2001) by introducing a superior instrument which is truly exogenous and a more accurate measure of what affected the settling decisions of European colonizers in establishing "inclusive" versus "extractive" institutions. 


\section{REFERENCES}

Acemoglu, Daron, Simon Johnson, and James A. Robinson. 2001. "The Colonial Origins of Comparative Development: An Empirical Investigation." The American Economic Review 91 (5): 1369-1401.

- 2002. "Reversal of Fortune: Geography and Institutions in the Making of the Modern World Income Distribution." Quarterly Journal of Economics 117 (4): 1231-1294.

Albouy, David. 2008. "The Colonial Origins of Comparative Development: An Investigation of the Settler Mortality Data." National Bureau of Economic Research Working Paper 14130.

—. 2012. "The Colonial Origins of Comparative Development: An Empirical Investigation: Comment.” American Economic Review 102 (6): 3059-76.

Besley, T., and M. Kudamatsu. 2006. "Health and Democracy." The American Economic Review 96 (2): 313-18.

Bound, John, David A. Jaeger, and Regina M. Baker. 1995. "Problems with Instrumental Variables Estimation When the Correlation Between the Instruments and the Endogeneous Explanatory Variable Is Weak." Journal of the American Statistical Association 90 (430). [American Statistical Association, Taylor \& Francis, Ltd.]: 443-50. http://www.jstor.org/stable/2291055.

Carstensen, K. and E. Gundlach. 2006. "The Primacy of Institutions Reconsidered: Direct Income of Malaria Prevalence.” World Bank Economic Review 20 (3). 
Development

Chao, John C., and Norman R. Swanson. 2005. "Consistent Estimation with a Large Number of Weak Instruments.” Econometrica 73 (5): 1673-92.

Cragg, J.G., and S.G. Donald. 1993. "Testing Identifiability and Specification in Instrumental Variables Models.” Econometric Theory 9: 222-40.

Gallup, J. L., and J. D Sachs. 2001. "The Economic Burden of Malaria.” American Journal of Tropical Medicine and Hygiene.

Gallup, J. L., J. D. Sachs, and A. D. Mellinger. 1999. "Geography and Economic Development.” International Regional Science Review 22 (2): 179-232.

Glaeser, E. L., R. La Porta, F. Lopez-de-Silanes, and A. Schleifer. 2004. "Do Institutions Cause Growth?” Journal of Economic Growth 9 (3): 271-303.

Gooch, E. 2017. "The Impact of Reduced Incidence of Malaria and other Mosquito-borne Diseases on Global Population." Journal of Development Economics, forthcoming.

Guo, Zhe, Jawoo Koo, Ulrike Wood-Sichra, Carlo Azzarri, and Melanie Bacou. 2015. “Argoecology, Demographics, Markets, Farming Systems, Agricultural R\&D: HarvestChoice 5-Arc Minute Spatial Layers for subSaharan Africa Release \{Version\}." HarvestChoice, IFPRI, University of Minnesota; Available on-line at http://www.harvestchoice.org/data/.

Hall, R.E. and Jones, C.I., 1999. 'Why do some countries produce so much more output per worker than others?". National bureau of economic research (No. w6564).

Hay, Simon I., Carlos A. Guerra, Andrew J. Tatem, Abdisalan M. Noor, and Robert W Snow. 2004. "The Global Distribution and Population at Risk of Malaria: Past, Present, and Future.” Lancet Infect Dis. 4 (8): 327-38. 
Hay, Simon I., David L. Smith, and Robert W. Snow. 2008. "Measuring the Malaria Endemicity from Intense to Interrupted Transmission." Lancet Infectious Diseases 8: 369-78.

Henderson, J. V., A. Storeygard, and D. N Weil. 2012. "Measuring Economic Growth from Outer Space.” American Economic Review 102 (2): 994 1028.

Kaufmann, Daniel, Aart Kraay, and Massimo Mastruzzi. 2010. "The World Governance Indicators: Methodology and Analytical Issues.” World Bank Policy Reasearch Working Paper No. 5430.

Kiszewski, Anthony, Andrew Mellinger, Andrew Spielman, Pia Malaney, Sonia Ehrlich Sachs, and Jeffery Sachs. 2004. "A Global Index Representing the Stability of Malaria Transmission.” The American Journal of Tropical Medicine and Hygiene 70 (5).

Klein Goldewijk, K., A. Beusen, and P. Janssen. 2010. "Long Term Dynamic Modeling of Global Population and Built-up Area in a Spatially Explicit Way, HYDE 3.1.” The Holocene 20: 565-73.

Klein Goldewijk, Kees. 2005. "Three Centuries of Global Population Growth: A Spatial Referenced Population (Density) Database for 1700-2000.” Population and Environment 26 (4): 343-67.

Knack, S. and Keefer, P., 1995. "Institutions and economic performance: crosscountry tests using alternative institutional measures". Economics \& Politics, 7(3), pp.207-227.

La Porta, R. and Lopez-de-Silanes, F., 1998. "Capital markets and legal institutions". Beyond the Washington consensus: Institutions matter, pp.73-92. 
Development

Lorentzen, P., J. McMillan, and R Wacziarg. 2008. "Death and Development." Journal of Economic Growth 13: 81-124.

Lysenko, A. J., and I. N. Semashko. 1968. "Geography of Malaria. a MedicoGeographic Profile of an Ancient Disease.” Medicinskaja Geografija, 25146.

MacDonald, G. 1952. "The Analysis of Equilibrium in Malaria." Tropical Disease Bulletin 49: 813-29.

Maddison-Project, The. 2013. "2013, Version.” http://www.ggdc.net/maddison/maddison-project/home.htm.

Mauro, P., 1995. "Corruption and growth". The quarterly journal of economics, pp.681-712.

McArthur, J. W. \& Sachs, J. D., 2001. "Institutions and geography: comment on Acemoglu, Johnson and Robinson (2000)”. National Bureau of Economic Reseach Working Paper 8114.

McCord, G.C. and Sachs, J.D., 2013. "Development, structure, and transformation: Some evidence on comparative economic growth”. National Bureau of Economic Research (No. w19512).

Michalopoulos, S., and E. Papaioannou. 2013. "Pre-Colonial Ethnic Institutions and Contemporary African Development." Econometrica 81 (1): 113-52.

Nordhaus, W. 2005. “Geography and Macroeconomics: New Data and New Findings." Proceeding of the National Academy of Sciences 103 (10): $3510-7$.

Nunn, N., and D. Puga. 2012. "Ruggedness: The Blessing of Bad Geography in Africa." The Review of Economics and Statistics 94 (1): 20-36. 
Nunn, N., and L. Wantechekon. 2011. "The Slave Trade and the Origins of Mistrust in Africa." American Economic Review 101 (7): 3221-52.

Rodrik, D., 1999. “The new global economy and developing countries: making openness work”. Overseas Development Council (Vol. 24). Washington, DC.

Rodrik, D., A. Subramanian, and F. Trebbi. 2004. "Institutions Rule: The Primacy of Institutions over Geography and Integration in Economic Development." Journal of Economic Growth 9 (2): 131-65.

Ross, Ronald. 1911. The Prevention of Malaria. London: John Murray.

Sachs, J. and P. Malaney. 2002. "The Economic and Social Burden of Malaria." Nature 415: 680-685.

Sachs, J. D., 2012. Reply to Acemoglu and Robinson's response to my book review. [Online] Available at: http://jeffsachs.org/2012/12/reply-toacemoglu-and-robinsons-response-to-my-book-review/ [Accessed 11 January 2016].

Stock, J.H., and M. Yogo. 2005. "Testing for Weak Instruments in Linear IV Regression." In Indentification and Inference for Econometric Models Essays in Honor of Thomas Rothenberg, edited by D.W.K Andrews and J.H Stock, 80-108. Cambridge: Cambridge University Press. 